University of Texas Rio Grande Valley

ScholarWorks @ UTRGV

Management Faculty Publications and

Presentations

Robert C. Vackar College of Business \& Entrepreneurship

$9-2020$

\title{
Female CEO Leadership and the Likelihood of Corporate Diversity Misconduct: Evidence from S\&P 500 Firms
}

Hazel H. Dadanlar

The University of Texas Rio Grande Valley

Michael A. Abebe

The University of Texas Rio Grande Valley, michael.abebe@utrgv.edu

Follow this and additional works at: https://scholarworks.utrgv.edu/mgmt_fac

Part of the Business Administration, Management, and Operations Commons

\section{Recommended Citation}

Dadanlar, Hazel H., and Michael A. Abebe. "Female CEO Leadership and the Likelihood of Corporate Diversity Misconduct: Evidence from S\&P 500 Firms." Journal of Business Research 118 (September 2020): 398-405. https://doi.org/10.1016/j.jbusres.2020.07.011.

This Article is brought to you for free and open access by the Robert C. Vackar College of Business \& Entrepreneurship at ScholarWorks @ UTRGV. It has been accepted for inclusion in Management Faculty Publications and Presentations by an authorized administrator of ScholarWorks @ UTRGV. For more information, please contact justin.white@utrgv.edu,william.flores01@utrgv.edu. 


\begin{abstract}
Large-scale discrimination lawsuits-as major types of corporate diversity misconduct-pose significant challenges for the reputation and financial well-being of firms. This study explores the role female CEOs play in reducing the likelihood of such lawsuits. Drawing from social role theory, we propose that female CEOs, given their high-profile position, past career experiences and general sensitivity to diversity misconduct, play a critical role in minimizing the occurrences of discrimination lawsuits. We tested our predictions using a panel data from S\&P 500 U.S. firms between 2010-2015. The findings indicate that firms that are led by female CEOs have a reduced likelihood of discrimination lawsuits. Furthermore, female CEOs can be particularly effective in reducing such lawsuits in firms with more frequent past diversity misconduct. Finally, our findings show that female CEO-led firms with favorable diversity ratings experience reduced likelihood of large-scale discrimination lawsuits. Implications for research and practice are discussed.
\end{abstract}

Keywords: Female CEOs, Diversity misconduct, Discrimination lawsuits, Social role theory, Strategic leadership 


\section{Female CEO Leadership and the Likelihood of Corporate Diversity Misconduct: Evidence from S\&P 500 Firms}

\section{Introduction}

Large-scale discrimination lawsuits-as major types of corporate diversity misconduct-pose significant challenges for firms' financial well-being and reputation among stakeholders and society at large. From the financial standpoint, there are considerable consequences of being named as a defendant in a large-scale discrimination lawsuit. For instance, research shows that the announcement of such lawsuits engenders an adverse reaction from investors as they anticipate the substantial financial commitment required in resolving these legal challenges (Wright et al., 1995; Bhagat et al., 1998; Hirsh \& Cha, 2015). In addition to the financial implications, firms involved in such lawsuits often face negative media coverage and, depending on the outcome of the case, a tarnished reputation among stakeholders (Tan, 2016). Such a 'reputational penalty' (Karpoff, 2012) makes it difficult for firms to continue to rely on the support of their key stakeholders. Given these financial and reputational consequences of largescale discrimination lawsuits, there is a growing emphasis on preventing the occurrences of these lawsuits in the first place and effectively manage them once they do (James \& Wooten, 2006; Burns, 2012). Corporate leaders (e.g. Chief Executive Officers (CEOs), senior executives, and board of directors (BODs) play a vital role in the management of these lawsuits (Bell et al., 2002). The CEO, in particular, holds a critical leadership position in averting corporate diversity misconducts such as large-scale discrimination lawsuits given his/her responsibilities in establishing organization-wide ethical norms and practices (Carlson \& Perrewe, 1995; Jones Christensen et al., 2014).

Beyond the overall observation on the important role of senior leaders, however, empirical evidence that demonstrates the leadership effect is at the nascent stage. While recent scholarly 
works have begun to examine the role corporate leaders play in effectively managing corporate litigation in general (e.g. Hutton et al., 2015), much work remains to be done in understanding whether and how corporate leaders, specifically the CEO, help minimize the occurrences of large-scale discrimination lawsuits.

In this study, we seek to contribute to research in this area by focusing on the role female CEOs play in managing large-scale discrimination lawsuits. Despite the literature on the antecedents (Glass \& Cook, 2016) and consequences (Cook and Glass, 2011) of female CEO appointments, there is a paucity of research exploring whether female CEOs are more effective in fostering a favorable diversity rating. In this study, we address this research gap by examining female CEOs' role in minimizing the occurrences of large-scale discrimination lawsuits. We argue that female CEOs, given their high-profile position, past career experiences and general sensitivity to diversity misconduct (Bell et al., 2002), play a critical role in minimizing the occurrences of discrimination lawsuits. We draw from social role theory (Eagly, 1987) and empathy-based logic in making this argument. We test our predictions using a panel dataset of U.S.-based, publicly traded firms in the Standard \& Poor (S\&P) 500 index.

This study makes a number of theoretical contributions to the corporate governance and business ethics literature. First, our study builds on the extant business ethics and leader gender diversity literatures that showed the significant impact female representation in the upper echelons has on firm financial and social performance (e.g. Boulouta, 2013; Byron \& Post, 2016). Specifically, our study contributes to this literature by showing how female CEOs alleviate the undesirable consequences of organizational diversity misconduct and thereby contribute to firm performance. Second, by employing past diversity misconduct as a moderator and favorable diversity rating as a mediator, we empirically show the context in which female 
CEOs are most effective in reducing the occurrences of large-scale discrimination lawsuits as well as the mechanism through which their influence unfolds

\section{Theory and Hypothesis Development}

\subsection{Large-Scale Discrimination Lawsuits as Organizational Crisis Contexts}

Large-scale discrimination lawsuits represent important organizational crisis contexts that significantly affect not only the firm's financial performance but also its reputation among its internal and external stakeholders (James \& Wooten, 2006). Research has shown that the announcement of a firm being named as a defendant in large-scale lawsuit results in a negative stock market reaction and a significant loss in its market valuation (Koku, 2006). Furthermore, large financial settlements or court verdicts can adversely affect the financial position of the firm by redirecting slack resources from other productive investments (Hirsh \& Cha, 2015). As the growing number of workplace discrimination lawsuits and their associated financial burden suggest, large-scale discrimination lawsuits represent a major organizational crisis context. In addition to the financial consequences, large-scale lawsuits in general and discrimination lawsuits in particular, can be harmful for the reputation of the firm (James \& Wooten, 2006; Karpoff, 2012). Firms mired in discrimination lawsuits face criticisms and public scrutiny on their workplace policies and practices from the media. Negative media accounts can tarnish reputation of these firms by characterizing them as less committed to a diverse and tolerant workplace. Further, firms facing such allegations suffer a backlash from prospective employees and other external business partners (Hirsh \& Cha, 2015).

\subsection{Female Leaders and Gender Role Expectations-A Social Role Theory Perspective}

In explaining the underlying dynamics of the relationship between female leaders and corporate diversity misconduct, we rely on insights from social role and gender socialization theories. Social role theory (Eagly, 1987) provides a cogent theoretical explanation on the 
sources of gender differences in social behavior. According to the proponents of this theory, gender differences in social behavior emerge primarily because of socially-sanctioned gender role expectations that are ingrained in every day social interactions. Social role theory is based on the extensive scholarly work on gender stereotypes that explored how commonly held social stereotypes shape the behavior of men and women. According to this theory, women are often expected to behave in a 'communal' approach with emphasis on showing concern for others, friendliness and generally unselfish behavior. On the other hand, men are expected to exhibit 'agentic' approaches such as independence, assertiveness and competence. The key tenets of social role theory have been used to explore gender differences particularly in the realm of leadership (Franke et al., 1997). Female leaders, fully recognizing the socially sanctioned role expectations they face, behave accordingly in order to receive the support of their followers and other stakeholders (Eagly \& Johnson, 1990). Additionally, past works have pointed to the presence of societal expectations that female leaders show compassion and display higher 'ethical concern' than their male counterparts (Gilligan, 1982; Kennedy \& Kray, 2014).

\subsection{Why Might Female CEO Leadership Reduce the Likelihood of Discrimination Lawsuits?}

While all CEOs are responsible for maintaining a discrimination-free workplace, we argue in this paper that female CEOs can be particularly effective in reducing the likelihood of discrimination lawsuits. Studies have shown that senior female corporate leaders, including female CEOs, are more likely to support and promote other female and minority employees in executive and supervisory positions compared to their male counter-parts (Matsa \& Miller, 2011; Cohen \& Broschak, 2013). Female CEOs' emphasis in supporting the career development of other women and minorities in the organization has important implications for the work climate. As more women hold leadership positions in the organization, they are less likely to tolerate 
diversity misconduct in the form of discriminatory and hostile work environment (Bell et al, 2002; Semuels, 2016).

Past research suggests that the demographic similarity of employees and their supervisors is an important factor that mitigates the perception of workplace discrimination (Avery et al., 2008). In addition to providing support to women and minorities, female CEOs may help reduce the occurrences of discrimination lawsuits by instituting organization wide policies and procedures that specifically promote "restorative justice" with respect to diversity misconduct (Bies et al., 2016). Female CEOs, as part of their journey climbing the 'corporate ladder', are more likely to have either personally experienced various forms of workplace discrimination (Bigelow et al., 2014) or know of colleague(s) who were victims of dysfunctional workplace behaviors (Bell \& Nkomo, 2001). These personal experiences provide them with a deeper understanding and empathy on the adverse effects of workplace discrimination, as such practices tend to make employees less productive and disengaged from organizational life (Volpone \& Avery, 2013). Based on these arguments, we propose the following hypothesis:

H1. The Presence of Female CEOs is negatively related to the Likelihood of Large-Scale Discrimination Lawsuits.

\subsection{Past Diversity Misconduct as a Moderator}

A firm's likelihood of facing discrimination lawsuit can be associated with prevailing organizational practices and policies relating to workplace diversity (Gelfand et al., 2005). Accordingly, the extent of past diversity misconduct (i.e. frequency of large-scale discrimination lawsuits) can be an important contingency variable that further facilitates female CEOs' role in mitigating the occurrences of discrimination lawsuits. Persistent organizational diversity misconduct creates a sense of urgency among BODs and external stakeholders (James \& Wooten, 2005). Firms dealing with past diversity misconduct often become targets of negative 
media coverage and other external stakeholders (such as regulators and community activists) for their alleged workplace practices (Hirsh \& Cha, 2015). Consequently, the negative media coverage these lawsuits attract can potentially lead to a withdrawal of support from suppliers, customers and to some extent, creditors (Tan, 2016). Such a stakeholder backlash creates a sense of urgency for immediate and substantive actions in order to improve the firm's record of diversity misconduct and thereby mitigate the unfavorable media coverage and public criticism that result from such misconduct (Haslem et al., 2017).

One major consequence of this sense of urgency is a push for CEO replacement. Scholars have shown that leadership changes often follow firms embroiled in multiple cases of large-scale discrimination lawsuits since such moves are considered symbolic and visible steps in mending the firm's tarnished reputation (James \& Wooten, 2006). Given the symbolic and substantive implications of CEO replacement, the appointment of female CEOs following persistent diversity misconduct is more likely to be viewed favorably by stakeholders. By appointing female CEOs, firms with considerable past diversity misconduct signal external stakeholders that they are 'cleaning up their acts' and are ready to make substantial changes in their internal policies and practices that relate to workplace diversity. Based on these arguments, we propose the following:

H2. The level of Past Diversity Misconduct significantly moderates the relationship between Female CEO Leadership and the Likelihood of Discrimination Lawsuits such that a female CEO will be more effective in reducing the likelihood of such lawsuits in firms with high levels of Past Diversity Misconduct.

\subsection{Female CEO Leadership and Favorable Diversity Rating}

Organization studies scholars have long shown that establishing and reinforcing organizational culture is one of the most important responsibilities of the CEO (Carlson \& Perrewe, 1995; Wu et al., 2015). Given their structural and symbolic position within the firm's 
hierarchy, CEOs are widely expected to articulate the key tenets of the organization's culture by implicitly and explicitly communicating what types of attitudes and behaviors are rewarded in the organization (Carlson \& Perrewe, 1995). CEOs play a critical role in developing, communicating and reinforcing ethical behavior throughout the organization (Ho et al., 2015). Consequently, when major ethical breaches arise, CEOs are often blamed for failing to provide ethical leadership in their words and actions.

In this study, we argue that, while all CEOs are expected to implement a favorable environment for diversity, female CEOs in particular are well positioned to develop, communicate and reward robust workplace policies and practices. First, female CEOs are more likely than their male counterparts to support a favorable environment for diversity because of their career experiences. Most female CEOs, if not all, tend to hold several mid-level managerial positions before their appointment to the CEO position. As they 'climb the corporate ladder', they are more likely to personally witness the unfortunate mistreatments and discriminatory behaviors in their workplace. They manage to reach their current executive position despite the unfavorable and unsupportive workplace policies. Accordingly, they are more likely to understand and sympathize with the outcomes of unfavorable environment for diversity.

In addition to the social role theory and empathy-based arguments, insights from social identity theory (Ashforth \& Mael, 1989; Tajfel \& Turner, 1985) may also provide additional explanations as to why female CEO leadership will foster favorable diversity rating. According to the core arguments of this theory, individuals form their social identity by aligning themselves with socially developed categories or psychological groups (i.e. in-groups vs. out-groups) based on their perceived psychosocial and demographic similarities. The presence of in-groups with similar social attributes and out-groups with different attributes allow the individual to develop a 
reference point in his/her attempt to develop a social identity. Drawing from these insights, we anticipate that female CEOs are more likely to identify themselves with 'occupational minority' groups such as women and ethnic minorities (Cook \& Glass, 2014). Accordingly, female CEOs' identification to these groups that have historically been targets of workplace discrimination allows them to serve as their advocates and pursue a favorable workplace diversity climate.

Finally, we believe female CEOs will be more likely to pursue favorable environment for diversity because of their 'ethical sensitivities' and tendency to voice their concern when they observe ethical and moral lapses (Simga-Mugan et al., 2005; Kennedy \& Kray, 2014). Research, for instance, has shown that women exhibit significantly higher "moral outrage" when presented with scenarios involving ethical compromises compared to men (Kennedy \& Kray, 2014). In sum, we propose that female CEOs, given their personal career experiences, ethical dispositions and socially constructed gender role expectations, are more likely to develop, communicate and implement robust workplace policies and practices that foster favorable diversity environment. Based on these arguments, we propose the following hypothesis:

H3. The Presence of Female CEOs is positively related to Favorable Diversity Rating. 2.6. How Female CEO Leadership Reduces the Likelihood of Discrimination LawsuitsFavorable Diversity Rating as a Mediator

Beyond understanding the relationship between female CEO leadership and the likelihood of discrimination lawsuits, it is also important to examine the intervening mechanisms through which such a relationship unfolds. Past scholarly works have explored the various contextual factors that influence legal compliance and likelihood of corporate litigation. Specifically, the organizational (e.g. Avery et al., 2008) and capital market (e.g. Hirsh \& Cha, 2015) correlates of corporate litigation have been well-documented. Similarly, sociology scholars have also examined how the legal and political climate (Skaggs, 2009) as well as 
variations in local/regional contexts (Tomaskovic-Devey \& Stainback, 2007; Stainback \& Tomaskovic-Devey, 2012) influence legal compliance and corporate discrimination lawsuits.

In this study, we extend research in this area by suggesting that female CEOs' active support for favorable diversity rating makes them effective in reducing the likelihood of discrimination lawsuits. We base this argument on insights from an extensive line of scholarly work in psychology and social psychology that has explored the differences in ethical orientation between men and women (Gilligan, 1982; Kennedy \& Kray, 2014). Gilligan (1982)'s work, in particular, showed that women prefer relational (care-focused) moral reasoning including compassion, care and empathy while men lean more toward justice (fairness-focused) approaches in their moral reasoning.

In the governance literature, a number of studies have shown that female leaders are more inclined to pursue an organizational climate that supports workforce diversity (Boulouta, 2013; Mattis, 2001). Female leaders also foster a favorable diversity environment by consistently and passionately communicating with organizational members that any form of discriminatory conduct will not be tolerated in the organization. Female leaders are, in particular, uniquely positioned to articulate such a message given the challenges of workplace discrimination they often face in their careers (Bell \& Nkomo, 2001). Based on these arguments, we propose the following:

H4. Favorable Diversity Rating mediates the relationship between Female CEO Leadership and the Likelihood of Large-Scale Discrimination Lawsuits.

\section{Methods}

\subsection{Sample and Data Sources}

To test our hypotheses, we relied on data from firms listed in the Standard \& Poor's 500 
(S\&P 500) index. Using this index allowed us to incorporate large firms from both manufacturing and service sectors covering diverse spectrum of industry groups. We considered all U.S-based and publicly traded firms from the S\&P 500 for the 2010-2015 period. Because we aimed to examine the effect of female CEO leadership on the likelihood of the discrimination lawsuit, we chose a more recent sampling window given the recent slight uptick in the number of female representations on both TMTs and boards (Catalyst-Pyramid: Women in S\&P 500 Companies, 2017). Since we only focus on U.S-based publicly traded firms for the purposes of this study, we relied on the Securities and Exchange Commission (SEC) filings in obtaining data on our variables. We identified 53 firms with missing proxy filings which were then excluded from the final sample. Consequently, our final sample consisted of 452 U.S-based, publicly traded firms. Given our six-year sampling window (2010-2015), our final panel dataset consisted of 2712 firm years (452 firms x 6 years). However, some missing data (especially in our control variables) reduced our analysis sample from 2712 firm years to 2006 in Table II and around 1800 in the remaining analyses.

We constructed a panel dataset based on various data sources. Data on our dependent variable, discrimination lawsuits, were collected from 'Justia dockets and filings', an online legal database (U.S. District Court and U.S. Court of Appeals Cases, Dockets and Filings, 2016). We chose to use Justia as it offers comprehensive lawsuit data compared to other similar data sources. This online database allowed us to identify all the lawsuits filed in federal appellate and district courts linked to Public Access to Court Electronic Records (PACER). The types of discrimination lawsuits included in our study reflect the U.S Equal Employment Opportunity Commission (EEOC)'s listings of discrimination lawsuits. We developed a two-step 'search \& selection' criteria to collect the discrimination lawsuit data. In the first step (search), we selected 
three lawsuit types (i.e. Americans with Disabilities, employment and labor) listed under the 'civil rights' drop-down menu option on 'Justia dockets and filings' website. These three lawsuit types provided us with all the Title VII, ADEA (Age Discrimination Lawsuits), ADA (Americans with Disabilities), and EPA (Equal Pay Lawsuit) legal cases brought against our sample firms. In the second step (selection), we thoroughly read the search results and determined whether the lawsuits pertained to the civil rights laws listed above. Consequently, we included a broad range of discrimination lawsuits including age, disability, equal pay/compensation, harassment, national origin, pregnancy, race/color, religion, gender, and sexual harassment as a result of this selection process. Data on BODs, CEOs and TMTs were obtained from SEC proxy filings, ExecuComp and BoardEx databases. Additionally, KLD and Mergent Online databases were used to gather data on our control variables.

\subsection{Measures}

Dependent Variable-The dependent variable of interest in this study is the Likelihood of Discrimination Lawsuits. We operationalized this variable using binary coding where a value of ' 1 ' was assigned if a firm was named in a discrimination lawsuit(s) as a defendant during the sampling window and ' 0 ' otherwise.

Independent Variable- The independent variable in our study is the presence of Female CEO Leadership. We coded this variable as binary, assigning ' 1 ' if a firm was led by a female CEO during the sampling window and ' 0 ' otherwise. The independent variable was lagged by a year from the dependent variable (likelihood of discrimination lawsuit) to establish temporal separation.

Moderating Variable- We included the Past Diversity Misconduct as our moderating variable to predict whether female CEOs are more effective in reducing the likelihood of discrimination 
lawsuits for firms with higher levels of past diversity misconduct. We operationalized this variable using a binary variable, assigning ' 1 ' if a firm was named as a defendant in at least one large-scale discrimination lawsuit during the four years prior to our sampling window (20062009) and '0' otherwise.

Mediating Variable- We coded our mediating variable- Favorable Diversity Rating- as ' 1 ' if our sample firms promote organization wide diversity initiatives (received a positive score in workforce diversity dimension in KLD database) and ' 0 ' otherwise. Specifically, data on positive social performance ratings (as it relates to the promotion of workforce diversity) for each firm in the KLD database was used. KLD database defines this variable as an indicator that is "designed to assess a firm's efforts to promote diversity in its workforce. Factors affecting this evaluation include, but are not limited to, its efforts to recruit women and minorities, and its participation in multi-stakeholder diversity initiatives.” (MSCI ESG KLD Methodology, 2015, p. 64).

Control Variables: To account for recognized predictors of discrimination lawsuits, we included managerial, organizational, and industry level control variables in our analyses. Our managerial level controls include CEO tenure, CEO turnover, and Proportion of female executives. We measured a CEO tenure by counting the number of years $\mathrm{s}(\mathrm{he})$ held the CEO position within our sampling window. We operationalized CEO turnover using a binary coding with a value of ' 1 ' if a firm had a CEO turnover during our sampling window (2010-2015), and ' 0 ' otherwise. The proportion of female executives was operationalized as the number of female executives (excluding the female CEO) divided by the total number of the TMT. We followed Bertrand et al (2003)'s definition of TMT size as the top five highest paid executives. We also controlled for board size and proportion of female directors. We operationalized proportion of female directors as the number of female directors divided by the total number of directors on 
the board. Finally, we also controlled for the potential effect board size may have on the likelihood of discrimination lawsuits. We measured this variable as the number of directors serving on sample firms' boards.

Organizational level controls included firm age, firm size, and firm past performance. Firm age was measured by simply subtracting the firm's incorporation year from the latest year in our sampling window (2015). The natural log of the number of employees was used to measure firm size. To control for past performance, we used the average return on assets (ROA). Finally, because firms in certain industry sectors have been shown to more likely involve in discrimination lawsuits, we controlled for sub-industry categories such as technology (software), hospitality and oil \& gas as lawsuit prone industries (Litvak, 2016; Sixel, 2016). We created a dummy variable coding sample firms in these industry categories as ' 1 ' and ' 0 ' otherwise. Finally, we created another industry level dummy variable- industry sector-to account for any potential influence a firm's membership in service or manufacturing sectors may have on the likelihood of discrimination lawsuits. Using SIC indicators, we coded the industry sector variable ' 1 ' if a sample firm is in the service sector and ' 0 ' if it operates in the manufacturing sector.

\subsection{Analytical Approach}

We employed a panel logistic regression analysis using the xtlogit command in Stata 15 given the binary nature of our dependent variable (likelihood of discrimination lawsuit) and a panel dataset. Marginal effects at the mean were calculated for each predictor to accurately interpret coefficient estimates (Wiersema \& Bowen, 2009). Our study focuses on exploring the effect of female CEO leadership on likelihood of discrimination lawsuits. Firms appointing female CEOs might be systematically different from those that do not (Faccio et al., 2016). While sample- 
induced endogeneity is unlikely given our use of the entire S\&P 500 firms, there is a possibility of omitted variable endogeneity in our study (Certo et al., 2016). For a panel data, a two-stage estimation approach is often recommended using the xtivreg command Stata (Cameron \& Trivedi, 2010). However, given our binary outcome variable, this command is not suitable for our study. Instead, we followed a modified two-step estimating procedure recommended by Vella and Verbeek (1999) to correct for our endogenous predictor. In the first stage probit model, we regressed a binary female CEO presence variable on a several predictors that have been shown to influence the likelihood of female CEO appointment. In particular, we used the proportion of female legislators in State legislatures in which our sample firms' headquarters are located in as one predictor since the level of relative gender equality has been shown to predict corporate leaders' greater gender diversity (Sugarman \& Straus, 1988). In addition, we included the proportion of industry female labor participation (4 digit SIC) as it was shown to influence the likelihood of female director appointments (Hillman et al., 2007). We used U.S. Bureau of Labor Statistics reports to collect data on female labor force participation rates and National Conference of State Legislatures (NCSL) website (http://www.ncsl.org/) for obtaining data on the percentages of female legislators in each state where sample firms were headquartered. Proportion of female directors, board size, firm age, firm size, past performance and the industry sector dummy were also added in the first stage probit model as predictors. We included the coefficients from the predicted value (phat) in the first stage estimation into our second stage (main) panel logistic regression analysis as a correction variable.

\section{Results}

Table 1 presents the means, standard deviations, and correlations of study's variables. The presence of a female CEO is positively correlated to the Proportion of female directors ( $\mathrm{r}=0.05$, 
$p<0.01)$ but is negatively correlated $(\mathrm{r}=-0.04, p<0.05)$ with CEO Tenure. The proportion of female Directors is positively correlated with Discrimination Lawsuits $(\mathrm{r}=0.09, p<0.01)$.

Insert Table 1 about Here

The results of our logit analyses are reported in Table 2 below. Models 1-3 in Table 2 report panel logistic regression coefficients while marginal effects at variable means are reported in the last column. Model 1 of Table 2 shows the coefficients for the control variables. As can be seen from Model 1, older firms and larger firms are more prone to discrimination lawsuits. Further, firms in the service industry sector are more likely to be involved in discrimination lawsuits. Hypothesis 1 proposed that the presence of female CEO is negatively related to likelihood of the discrimination lawsuits. Model 2 of Table 2 indicates that the Presence of Female CEOs has a statistically significant negative coefficient $(\mathrm{B}=-1.05, p<0.05)$ and marginal effect at mean (Marginal effect $=-0.09, p<0.05$ ). Accordingly, the marginal effect value for the Presence of Female $C E O$ indicates that, holding other variables at their means, the probability of a firm facing a discrimination lawsuit decreases by $9 \%$ if the firm is led by a female CEO. These significant coefficients provide empirical support for hypothesis 1(H1). The result for our moderation hypothesis (H2) is presented in Model 3 of Table 2.

Hypothesis 2 (H2) predicted that Past Diversity Misconduct moderates the relationship between female CEO leadership and the likelihood of discrimination lawsuits such that the presence of a female CEO will be more effective in reducing the likelihood of such lawsuits in firms with high levels of past diversity misconduct. The result in the Model 3 of Table 2 presents that the interaction term between the Presence of a Female CEO and the Past Diversity Misconduct was statistically significant as can be seen from the coefficient $(\mathrm{B}=-1.36, p<0.01)$ 
and marginal effect (Marginal effect $=-0.31, p<0.01)$. The marginal effect of the interaction term between Presence of Female CEOs and Past Diversity Misconduct indicates that, holding other variables at their means, firms led by female CEOs are $31 \%$ less likely to be involved in discrimination lawsuits when they have higher levels of past diversity misconduct. Accordingly, our moderating hypothesis $(\mathrm{H} 2)$ received empirical support. Hypothesis $3(\mathrm{H} 3)$ proposed that the presence of female CEOs is positively related to favorable diversity rating. As can be seen from Model 1 of Table 3 below, this hypothesis has received empirical support $(\mathrm{B}=1.51, p<0.05)$. The marginal effect of female CEO presence was 0.17 . Accordingly, the findings indicate that, after holding all other variables in the model at their mean, the presence of female CEOs is positively associated with $17 \%$ increase in the likelihood of favorable diversity rating.

Insert Table 2 about Here

Insert Table 3 about Here

Hypothesis $4(\mathrm{H} 4)$ predicts that a favorable diversity rating partially mediates the relationship between the presence of female CEOs and the likelihood of large-scale discrimination lawsuits. In order to test this mediating hypothesis, we followed the procedures outlined by MacKinnon et al. (2002) and Preacher \& Hayes (2004). These procedures primarily use a bootstrapping (resampling) technique to obtain confidence intervals.

Finally, we employed a binary mediation analysis (using 'binary mediation' command in Stata) given the binary nature of our mediating (diversity climate) and outcome (likelihood of discrimination lawsuit) variables (Ender, 2011). This analysis provides standardized coefficient estimates for direct, indirect and total effects between the independent, mediator and dependent 
variables. We utilized a bootstrapping technique to obtain bias-corrected confidence intervals (Ender, 2011) and the results are presented in Table 4 and 5 below. As shown in Tables 4 and 5, the result of the indirect relationship between Presence of Female CEO (IV) and Likelihood of Discrimination Lawsuit $(D V)$ through favorable diversity rating (Mediator) is statistically significant $(B=0.012)$ since the bias-corrected confidence intervals do not include the value of ' 0 ' in their range. While the direct effect is not statistically significant $(B=-0.043$, n.s. $)$, it is not considered a necessary condition to establish mediation relationship (Hayes, 2013). As Hayes (2013, p. 169) put it recently, “...there is a growing consensus among quantitative methodologists...that a total effect of $\mathrm{X}$ on $\mathrm{Y}$ should not be a prerequisite to searching for evidence of indirect effects." Accordingly, the statistically significant indirect effect provides empirical support for Hypothesis 4 (H4).

Insert Table 4 about Here

Insert Table 5 about Here

Overall, the empirical analyses present strong support for the negative relationship between the presence of female CEOs and the likelihood of discrimination lawsuits. Further, the findings indicate that this relationship becomes stronger in firms with persistent past diversity misconduct. Finally, the findings also provide support for our assertion that a favorable diversity rating serves as an intermediary process facilitating the link between female CEOs and occurrences of discrimination lawsuits.

\section{Discussion and Implications}

In this study, we explored the relationship between female CEOs and the likelihood of discrimination lawsuits as forms of diversity misconduct, arguing that by virtue of their career 
experiences and ethical dispositions, female CEOs are more effective in managing corporate diversity misconduct such as large-scale discrimination lawsuits. Our findings provide support for this argument suggesting that firms led by female CEOs have a lower likelihood of facing large-scale discrimination lawsuits. This finding contributes to the business ethics literature by highlighting the importance of female CEO leadership in mitigating the adverse consequences of organizational diversity misconduct. While our findings are in some cases consistent with other scholars' observation in this area (Bao et al., 2014), we believe that they are also distinct in a number of ways. Unlike Bao et al.' s (2014) single industry study, we used a broader sampling window and a larger sample size drawn from diverse industry sectors. Further, we have explained why female CEO leadership helps reduce the occurrences of discrimination lawsuits by emphasizing how socially sanctioned gender roles coupled with empathy-based motivations underlie their effectiveness. Specifically, since discrimination of any type firms involve in may adversely affect their social performance outcomes, our study contributes significant insights to this research stream by providing empirical evidence on women CEOs' role in influencing corporate social performance (e.g. Byron and Post, 2016).

Beyond establishing the female CEO-discrimination lawsuit relationship, we examined whether female CEOs are more effective in reducing the likelihood of discrimination lawsuits among firms with persistent past diversity misconduct. Our findings suggest that the presence of female CEOs can be especially helpful in reducing the likelihood of discrimination lawsuits in firms that had past diversity misconduct. Finally, our results indicate that female CEOs are able to reduce the likelihood of discrimination lawsuits by fostering a favorable diversity environment. Consequently, the findings of our study provide some insights into the mechanism through which female CEOs reduce the likelihood of discrimination lawsuits. This finding 
contributes to the current scholarly inquiry on the effect of female leaders on corporate outcomes by outlining a process model that explains how female CEOs help reduce corporate diversity misconduct. This is particularly important since a disproportionate amount of research in this area focuses on exploring the empirical link between female executive leadership and corporate outcomes and not necessarily on specifying the intermediate steps through which these relationships unfold (Faccio et al., 2016).

Finally, our findings also have some managerial implications. The significant negative relationship between female CEO leadership and the likelihood of discrimination lawsuits has implications for BODs' and shareholders' executive succession decisions. For shareholders, our

study's findings may provide insights on the importance of supporting female CEO appointments in order to reduce the chances of large-scale discriminations lawsuits. Furthermore, the findings also highlight female CEOs' ability to reduce the likelihood of discrimination lawsuits primarily through fostering a favorable diversity environment. Beyond the moral argument for gender diversity in executive and board positions, our findings may equip directors with information about female chief executives' strong influence on corporate diversity misconduct. Directors, armed with our study's findings, would be able to enhance their understanding that female CEOs, more so than female TMT members and directors, are the catalysts for creating a robust diversity climate that help reduce discrimination lawsuits.

\section{Limitations and Future Research Directions}

Despite its contributions, this study has a number of limitations. First, given our research questions and scope of inquiry, we were limited to measuring corporate diversity misconduct using a specific type of discrimination lawsuit (i.e. large-scale class-action lawsuits). While this is an appropriate operationalization for our study, future research could examine the link between 
female leadership in the upper echelons and corporate diversity in general using a primary (field) observation of firms. Similarly, while our study used a large-scale empirical analysis in its research design, future studies can use a mixed method approach that combines large scale empirical study with a qualitative research design to better understand how female leaders help cultivate a diverse workplace environment. Finally, we do not know much about how TMT members (including CEOs) and BODs with high levels of gender diversity process information in making organizational decisions. Consequently, future research should explore the decisionmaking process on boards and TMTs as a complex interaction rather than solely focusing on a single aspect of gender differences and their potential organizational and managerial implications.

\section{Conclusion}

This study examines the effect of female CEO leadership on the occurrences of large-scale discrimination lawsuits. The findings of our empirical study indicate that firms that are led by female CEOs have a reduced likelihood of discrimination lawsuits, particularly among firms with higher past diversity misconduct. Finally, our findings show that female CEO-led firms are associated with a favorable diversity ratings. Overall, the findings highlight the importance of female CEO leadership in minimizing the occurrences of organizational diversity misconduct.

\section{References}

About EEOC. (2016). Equal Employment Opportunity Commission. Retrieved December 20, 2016, from https://www.eeoc.gov/eeoc/index.cfm.

Ashforth, B. E., \& Mael, F. (1989). Social identity theory and the organization. Academy of Management Review, 14(1), 20-39.

Avery, D. R., McKay, P. F., \& Wilson, D. C. (2008). What are the odds? How demographic similarity affects the prevalence of perceived employment discrimination. Journal of Applied Psychology, 93(2), 235-249.

Bao, S., Fainshmidt, S., Nair, A., \& Vracheva, V. (2014). Women in upper echelons of management, tenure and legal risk. British Journal of Management, 25(2), 388-405.

Bell, E. L. E., \& Nkomo, S. M. (2001). Our separate ways: Black and white women and the 
struggle for professional identity. Harvard Business School Press, Boston, MA.

Bell, M. P., McLaughlin, M., \& Sequeira, J. (2002). Discrimination, harassment, and the glass ceiling: Women executives as change agents. Journal of Business Ethics, 37(1), 65.

Bertrand, M., Schoar, A., \& Thesmar, D. (2003). Banking deregulation and industry structure: Evidence from the French banking reforms of 1985. Mimeo, University of Chicago.

Bhagat, S., Bizjak, J., \& Coles, J. L. (1998). The shareholder wealth implications of corporate lawsuits. Financial Management, 5-27.

Bies, R. J., Barclay, L. J., Tripp, T. M., \& Aquino, K. (2016). A systems perspective on forgiveness in organizations. The Academy of Management Annals, 10(1), 245-318.

Bigelow, L., Lundmark, L., McLean Parks, J., \& Wuebker, R. (2014). Skirting the issues: Experimental evidence of gender bias in IPO prospectus evaluations. Journal of Management, 40(6), 1732-1759.

Boulouta, I. (2013). "Hidden connections: The link between board gender diversity and corporate social performance." Journal of Business Ethics 113(2): 185-197.

Burns, C. (2012). The costly business of discrimination: The economic costs of discrimination and the financial benefits of gay and transgender equality in the workplace. Center for American Progress.

Byron, K., \& Post, C. (2016). Women on boards of directors and corporate social performance: A meta-analysis. Corporate Governance: An International Review, 24(4), 428-442.

Carlson, D., \& Perrewe, P. (1995). Institutionalization of organizational ethics through transformational leadership. Journal of Business Ethics, 14(10), 829-838.

Cameron, A., \& Trivedi, P. (2010). Microeconometrics Using Stata. Stata Press, College Station, Texas.

Catalyst-Pyramid: Women in S\&P 500 Companies. (2017, August 22). Retrieved January 06, 2017, from http://www.catalyst.org/knowledge/women-sp-500-companies.

Certo, S., Busenbark, J., Woo, H.-S, \& Semadeni, M. (2016). Sample selection bias and Heckman models in strategic management research. Strategic Management Journal, 37(13), 2639-2657.

Cohen, L., \& Broschak, J. (2013). Whose Jobs Are These? The Impact of the Proportion of Female Managers on the Number of New Management Jobs Filled by Women versus Men. Administrative Science Quarterly, 58(4), 509-541.

Cook, A., \& Glass, C. (2011). Leadership change and shareholder value: How markets react to the appointments of women. Human Resource Management, 50(4), 501-519.

Cook, A., \& Glass, C. (2014). Above the glass ceiling: When are women and racial/ethnic minorities promoted to CEO? Strategic Management Journal, 35(7), 1080-1089.

Ender, P. (2011). Stata binary_mediation command to estimate indirect effects with a binary dependent variable and/or mediator variable. Retrieved from https://stats.idre.ucla.edu/stata/faq/how-can-i-perform-mediation-with-binary-variables/.

Eagly, A. H. (1987). Sex differences in social behavior: A social-role interpretation. Hillsdale, NJ, Earlbaum.

Eagly, A. H. and B. T. Johnson (1990). "Gender and leadership style: A meta-analysis." Psychological Bulletin 108(2): 233.

Franke, G., Crown, D., \& Spake, D. (1997). Gender differences in ethical perceptions of business practices: a social role theory perspective. Journal of Applied Psychology, 82(6), 920.

Faccio, M., Marchica, M.-T., \& Mura, R. (2016). CEO gender, corporate risk-taking, and the efficiency of capital allocation. Journal of Corporate Finance, 39, 193-209. 
Gelfand, M., Nishil, L., Raver, J., \& Schneider, B. (2005). Discrimination at work: The psychological and organizational bases. In R. L. Dipboye \& A. Colella (Eds.), The Organizational Frontiers Series (pp. 89-116). Mahwah, N.J.: Psychology Press.

Gilligan, C. (1982). In a different voice, Harvard University Press.

Glass, C., \& Cook, A. (2016). Leading at the top: Understanding women's challenges above the glass ceiling. The Leadership Quarterly, 27(1), 51-63.

Haslem, B., Hutton, I., \& Smith, A. H. (2017). How much do corporate defendants really lose? A new verdict on the reputation loss induced by corporate litigation. Financial Management, 46(2), 323-358.

Hayes, A. (2013). Introduction to mediation, moderation, and conditional process analysis: a regression-based approach. Guilford, New York.

Hillman, A. J., Shropshire, C., \& Cannella, A. A. (2007). Organizational predictors of women on corporate boards. Academy of Management Journal, 50(4), 941-952.

Hirsh, C. E., \& Cha, Y. (2015). Employment discrimination lawsuits and corporate stock prices. Social Currents, 2(1), 40-57.

Ho, S., Li, A., Tam, K., \& Zhang, F. (2015). CEO gender, ethical leadership, and accounting conservatism. Journal of Business Ethics, 127(2), 351-370.

Hutton, I., Jiang, D., \& Kumar, A. (2015). Political values, culture, and corporate litigation. Management Science, 61(12), 2905-2925.

James, E. H., \& Wooten, L. P. (2005). How to display competence in times of crisis. Organizational Dynamics, 34(2), 141-152.

James, E. H., \& Wooten, L. P. (2006). Diversity crises: How firms manage discrimination lawsuits. Academy of Management Journal, 49(6), 1103-1118.

Jones Christensen, L. I. S. A., Mackey, A., \& Whetten, D. (2014). Taking responsibility for corporate social responsibility: The role of leaders in creating, implementing, sustaining, or avoiding socially responsible firm behaviors. Academy of Management Perspectives, 28(2), 164-178.

Karpoff, J. M. (2012). Does reputation work to discipline corporate misconduct? In M. Barnett \& T. Pollock (Eds.), The Oxford Handbook of Corporate Reputation (pp. 361-382). Oxford, UK: Oxford University Press.

Kennedy, J. A. and L. J. Kray (2014). Who is willing to sacrifice ethical values for money and social Status? Gender differences in reactions to ethical compromises. Social Psychological and Personality Science 5(1): 52-59.

Koku, P. S. (2006). An analysis and the effects of class-action lawsuits. Journal of Business Research, 59(4), 508-515.

Litvak, A. (2016, January 24). Oil, gas firms faced dozens of discrimination suits in past decade. Pittsburgh Post-Gazette.

MacKinnon, D. P., Lockwood, C. M., Hoffman, J. M., West, S. G., \& Sheets, V. (2002). A comparison of methods to test mediation and other intervening variable effects. Psychological Methods, 7(1), 83-104.

Matsa, D. A., \& Miller, A. R. (2011). Chipping away at the glass ceiling: Gender spillovers in corporate leadership. American Economic Review, 101(3), 635-639.

Mattis, M. C. (2001). Advancing women in business organizations: Key leadership roles and behaviors of senior leaders and middle managers. Journal of Management Development, 20(4), 371-388. 
MSCI KLD 400 Social Index Methodology. (2015, June). Retrieved September 1, 2018, from https://www.wiso.unihamburg.de/bibliothek/recherche/datenbanken/unternehmensdaten/msci-methodology2014.pdf.

Preacher, K. J., \& Hayes, A. F. (2004). SPSS and SAS procedures for estimating indirect effects in simple mediation models. Behavior Research Methods, Instruments, \& Computers, 36(4), 717-731.

Semuels, A. (2016, December 27). Female Bosses in the Workplace: What happens to employees under female leadership? The Atlantic.

Simga-Mugan, C., Daly, B. A., Onkal, D., \& Kavut, L. (2005). The influence of nationality and gender on ethical sensitivity: An application of the issue-contingent model. Journal of Business Ethics, 57(2), 139-159.

Sixel, L. (2016, January 6). Sex, race, disability claims remain EEOC's chief focus. Houston Chronicle.

Skaggs, S. (2009). Legal-political pressures and African American access to managerial jobs. American Sociological Review, 74(2), 225-244.

Stainback, K., \& Tomaskovic-Devey, D. (2012). Documenting desegregation: Racial and gender segregation in private sector employment since the Civil Rights Act: Russell Sage Foundation.

Sugarman, D., \& Straus, M. (1988). Indicators of gender equality for American states and regions. Social Indicators Research, 20(3), 229-270.

Tajfel, H., \& Turner, J. (1985). The social identity theory of intergroup behavior. In S. Worchel \& W. G. Austin (Eds.), Psychology of Intergroup Relations (2nd ed., pp. 7-24). Chicago, IL: Nelson-Hall.

Tan, D. (2016). Making the news: Heterogeneous media coverage and corporate litigation. Strategic Management Journal, 37(7), 1341-1353.

Tomaskovic-Devey, D., \& Stainback, K. (2007). Discrimination and desegregation: Equal opportunity progress in US private sector workplaces since the Civil Rights Act. The Annals of the American Academy of Political Social Science, 609(1), 49-84.

U.S. district court and U.S. court of appeals cases, dockets and filings. (n.d.). Retrieved August 02, 2017, from https://dockets.justia.com/.

Vella, F., \& Verbeek, M. (1999). Two-step estimation of panel data models with censored endogenous variables and selection bias. Journal of Econometrics, 90(2), 239-263.

Volpone, S. D., \& Avery, D. (2013). It's self-defense: How perceived discrimination promotes employee withdrawal. Journal of Occupational Health Psychology, 18(4), 430-448.

Wiersema, M. F., \& Bowen, H. P. (2009). The use of limited dependent variable techniques in strategy research: issues and methods. Strategic Management Journal, 30(6), 679-692.

Wright, P., Ferris, S. P., Hiller, J. S., \& Kroll, M. (1995). Competitiveness through management of diversity: Effects on stock price valuation. Academy of Management Journal, 38(1), 272-287.

Wu, L.-Z., Kwan, H., Yim, F., Chiu, R., \& He, X. (2015). CEO ethical leadership and corporate social responsibility: A moderated mediation model. Journal of Business Ethics, 130(4), 819-831. 
Table 1. Descriptive Statistics and Correlations

\begin{tabular}{|c|c|c|c|c|c|c|c|c|c|c|c|c|c|c|c|}
\hline & Variables & Mean & SD & 1 & 2 & 3 & 4 & 5 & 6 & 7 & 8 & 9 & 10 & 11 & 12 \\
\hline 1 & Firm Age & 56.36 & 39.74 & 1 & & & & & & & & & & & \\
\hline 2 & Firm Size $^{1}$ & 9.81 & 1.48 & $0.25^{* * *}$ & 1 & & & & & & & & & & \\
\hline 3 & Past Performance $^{2}$ & 6.13 & 6.62 & $0.11 * * *$ & $0.11 * * *$ & 1 & & & & & & & & & \\
\hline 4 & $\begin{array}{l}\text { Proportion of } \\
\text { Female Directors }\end{array}$ & 0.18 & 0.09 & $0.21 * * *$ & $0.16^{* * * *}$ & $-0.05 * * *$ & 1 & & & & & & & & \\
\hline 5 & Board Size & 10.71 & 2.32 & $0.17 * * *$ & $0.27 * * *$ & $-0.10 * * *$ & -0.00 & 1 & & & & & & & \\
\hline 6 & CEO Tenure & 10.27 & 6.66 & $-0.08 * * *$ & 0.02 & $0.07 * * *$ & $-0.14 * * *$ & $-0.12 * * *$ & 1 & & & & & & \\
\hline 7 & CEO Turnover & 0.53 & 0.49 & $0.09 * * *$ & $-0.01 * * *$ & -0.004 & $0.03 *$ & $0.03 *$ & $-0.17 * * *$ & 1 & & & & & \\
\hline 8 & $\begin{array}{l}\text { Prop. of Female } \\
\text { Executives }\end{array}$ & 0.12 & 0.17 & 0.01 & 0.01 & 0.00 & $0.12 * * *$ & $-0.03 *$ & -0.02 & -0.01 & 1 & & & & \\
\hline 9 & $\begin{array}{l}\text { Past Diversity } \\
\text { Misconduct }\end{array}$ & 0.69 & 1.88 & $0.11 * * *$ & $0.37 * * *$ & -0.00 & $0.08 * * *$ & $0.15 * * *$ & -0.02 & $0.08 * * *$ & $0.10 * * *$ & 1 & & & \\
\hline 10 & $\begin{array}{l}\text { Favorable } \\
\text { Diversity Rating }\end{array}$ & 0.35 & 0.48 & $0.15^{* * *}$ & $0.33 * * *$ & $0.04 * *$ & $0.18 * * *$ & $0.22 * * *$ & $-0.07 * * *$ & -0.003 & $0.04 *$ & $0.09 * *$ & 1 & & \\
\hline 11 & $\begin{array}{l}\text { Lawsuit Prone } \\
\text { Industries }\end{array}$ & 0.13 & 0.33 & $-0.17 * * *$ & $-0.17 * * *$ & $0.12 * * *$ & $-0.16 * * *$ & $-0.25 * * *$ & $0.08 * * *$ & $0.06 * * *$ & $-0.19 * * *$ & $-0.06 * * *$ & $-0.11 * * *$ & 1 & \\
\hline 12 & Female CEO & 0.04 & 0.20 & $0.10 * * *$ & $0.08 * * *$ & 0.00 & $0.05 * * *$ & 0.01 & $-0.04 * *$ & $0.07 * * *$ & 0.00 & 0.02 & -0.00 & $0.07 * * *$ & 1 \\
\hline 13 & $\begin{array}{l}\text { Discrimination } \\
\text { Lawsuits }\end{array}$ & 0.39 & 0.48 & $0.18 * * *$ & $0.36 * * *$ & 0.01 & $0.09 * * *$ & $0.10 * * *$ & 0.00 & 0.02 & $0.04 * * *$ & 0.02 & $0.28 * * *$ & $0.15^{* * *}$ & $-0.15 * * *$ \\
\hline
\end{tabular}

$* p<0.10$

$* * p<0.05$

$* * * p<0.01$

${ }^{1}$ Log. of employees

${ }^{2}$ Average $R O A, N=2712$ 
Table 2. The Effect of Female CEO Leadership on Likelihood of Corporate Discrimination Lawsuits (Panel Logistic Analysis) ${ }^{a}$

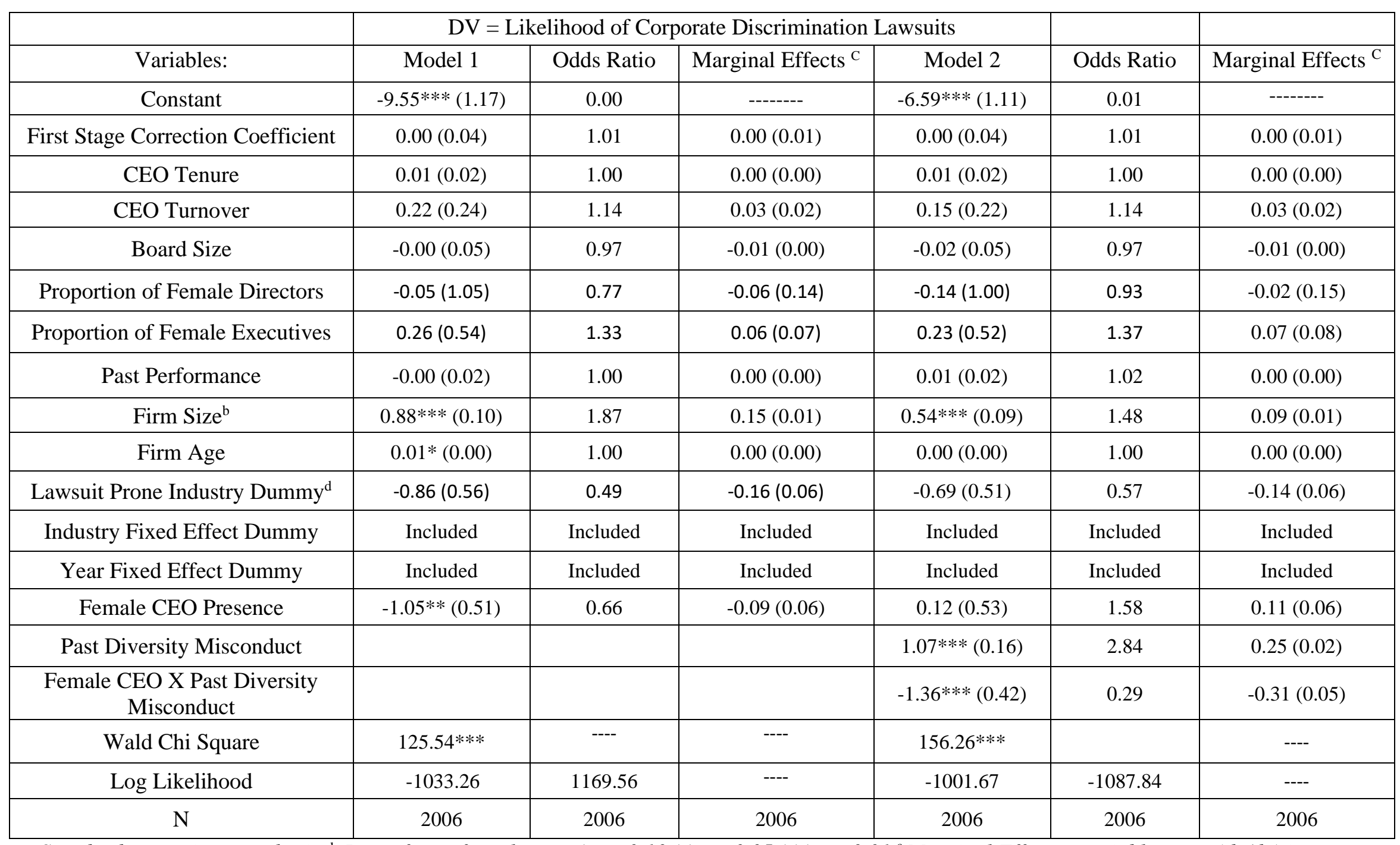

${ }^{\mathrm{a}}$ Standard errors in parenthesis ${ }^{\mathrm{b}}$ Log. of no. of employees, ${ }^{*} p<0.10 * * p<0.05 * * * p<0.01^{c}$ Marginal Effect at variable mean (dy/dx) is reported. ${ }^{d}$ Lawsuit prone industry dummy $=1$ for firms in technology (software), hospitality and oil \& gas 4 digit SIC codes 
Table 3. Female CEOs and Favorable Diversity Rating (panel logistic analysis) ${ }^{\mathrm{a}}$

\begin{tabular}{|c|c|c|c|}
\hline & \multicolumn{3}{|c|}{ DV = Favorable Diversity Rating } \\
\hline Variables: & Model 1 & Odds Ratio & Marginal Effects ${ }^{b}$ \\
\hline Constant & $-2.281(0.39) * * *$ & 0.30 & -------- \\
\hline Proportion of Female Directors & $4.036(1.42)^{* * *}$ & 37.17 & $0.443(0.16)$ \\
\hline $\begin{array}{c}\text { Proportion of Female } \\
\text { Executives in TMT }\end{array}$ & $0.358(0.67)$ & 1.81 & $0.039(0.07)$ \\
\hline Past Diversity Misconduct & $0.344(0.10)^{* * *}$ & 1.24 & $0.038(0.010)$ \\
\hline $\begin{array}{l}\text { Lawsuit Prone Industry } \\
\text { Dummy }^{\mathrm{c}}\end{array}$ & $-0.256(0.52)$ & 1.02 & $-0.028(0.057)$ \\
\hline Industry Fixed Effect Dummy & Included & Included & Included \\
\hline Year Fixed Effect Dummy & Included & Included & Included \\
\hline Female CEO Presence & $1.51(0.71)^{* *}$ & 1.91 & $0.17(0.08)$ \\
\hline Chi Square & $57.89 * * *$ & ---- & ---- \\
\hline -2 Log Likelihood & -883.98 & -1084.63 & ---- \\
\hline $\mathrm{N}$ & 1803 & 1803 & 1803 \\
\hline
\end{tabular}

$\mathrm{N}=1803{ }^{\text {a }}$ Standard errors in parenthesis

Binary Dependent Variable **p $<0.05, * * * p<0.01$

${ }^{b}$ Marginal Effect at variable mean $(d y / d x)$ is reported.

${ }^{c}$ Lawsuit prone industry dummy $=1$ for firms in technology (software), hospitality and oil \& gas 4 digit SIC codes 
Table 4. Binary Mediation Results-Presence of Favorable Organizational Diversity Climate as a Mediator

\begin{tabular}{|c|c|c|c|c|c|}
\hline Path & $\begin{array}{l}\text { Independent Variable } \\
\text { (IV) }\end{array}$ & $\begin{array}{l}\text { Dependent Variable } \\
\text { (DV) }\end{array}$ & $\begin{array}{c}\text { Logistic } \\
\text { Regression } \\
\text { Coefficient }\end{array}$ & Standard Error & Log Likelihood \\
\hline Direct (IV-DV) & $\begin{array}{l}\text { Presence of Female } \\
\text { CEO }\end{array}$ & $\begin{array}{c}\text { Likelihood of } \\
\text { Discrimination Lawsuit } \\
\end{array}$ & -0.291 & 0.254 & -1214.82 \\
\hline IV-Mediator & $\begin{array}{c}\text { Presence of Female } \\
\text { CEO }\end{array}$ & $\begin{array}{c}\text { Favorable Diversity } \\
\text { Rating }\end{array}$ & $0.659 * * *$ & 0.241 & -1190.33 \\
\hline \multirow{2}{*}{$\begin{array}{c}\text { Indirect (IV \& } \\
\text { Mediator on DV) }\end{array}$} & $\begin{array}{c}\text { Presence of Female } \\
\text { CEO }\end{array}$ & \multirow{2}{*}{$\begin{array}{c}\text { Likelihood of } \\
\text { Discrimination Lawsuit }\end{array}$} & -0.405 & 0.258 & \multirow{2}{*}{-1193.75} \\
\hline & $\begin{array}{c}\text { Favorable Diversity } \\
\text { Rating }\end{array}$ & & $0.645^{* *}$ & 0.099 & \\
\hline
\end{tabular}

\footnotetext{
$* p<0.10$

$* * p<0.05$

$* * * p<0.01 \quad N=1808$
}

Table 5. Binary Mediation with Bias Corrected Confidence Intervals

\begin{tabular}{|c|c|c|c|c|}
\hline & Coefficient & $\begin{array}{c}\text { Bootstrap } \\
\text { Standard } \\
\text { Error }\end{array}$ & Bias-corrected Confidence Interval (95\%) \\
\cline { 4 - 5 } & & Lower bound CI & Upper Bound CI \\
\hline $\begin{array}{c}\text { Indirect Effect } \\
\text { (IV to DV via } \\
\text { Mediator) }\end{array}$ & $\mathbf{0 . 0 1 2}$ & $\mathbf{0 . 0 0 5}$ & $\mathbf{0 . 0 0 5}$ & $\mathbf{0 . 0 2 5}$ \\
\hline Direct Effect & -0.043 & 0.027 & -0.10 & 0.007 \\
\hline Total Effect & -0.031 & 0.028 & -0.089 & 0.021 \\
\hline
\end{tabular}

$\boldsymbol{D} \boldsymbol{V}=$ Likelihood of Discrimination Lawsuit $; \boldsymbol{I V}=$ Presence of Female CEO

Mediator $=$ Favorable Diversity Ranking

Number of Observations $=1808 ;$ Bootstrap Replications $=500$ 